\title{
BUSINESS CYCLE CO-MOVEMENT BETWEEN AFRICA AND ADVANCED ECONOMIES: 1980-2011
}

\author{
Claassen, C*; Loots, E \#; Kabundi, A॰; Viviers W*
}

\begin{abstract}
The decoupling hypothesis has attracted growing research interest since the Global Financial Crisis (GFC). However, there is a lack of evidence on patterns of business cycle co-movement for Africa specifically. This paper fills the gap in the literature by analysing business cycle co-movement between African economies and Advanced Economies (AEs) using annual data which cover the period 1980 to 2011. Although the sample does not allow for a close-up investigation of the crisis years in particular, it does provide an overview of the period before, during and immediately after the GFC. In terms of methodology, a Dynamic Factor Model (DFM) was applied, which includes African and Group of Seven (G7) countries. The empirical analysis divides the African countries into four groups, namely low-income countries, middle-income countries, oil-exporting countries and fragile states. The results show evidence of strong comovement between, on the one hand, the middle-income African countries and the $\mathrm{G} 7$, and, on the other hand, the middle-income African countries themselves. The results identify trade linkage as the key driving force behind the co-movement of the business cycle. However, the oil-exporting and low-income African countries exhibit a low co-movement of the business cycle after controlling for common effects from the G7 countries. Interestingly, after the GFC, they decouple from the AEs. Finally, the results do not show signs of comovement with fragile states.
\end{abstract}

\section{$1 \quad$ Introduction}

After the 1980s, sometimes referred to as the 'lost decade' for Africa, the continent began to make positive economic strides once again. Since the 1990s, in particular, a previously much-insulated Africa has become more integrated into the global

\footnotetext{
* * School of Economics and TRADE research entity, North-West University

\# Department of Economics, Faculty of Economic and Management Sciences, University of Pretoria.

Elsabe.loots@up.ac.za (Corresponding author)

- South African Reserve Bank and Economic Research Southern Africa (ERSA))
} 
economy (Sahn \& Younger, 2004). For this reason, the Global Financial Crisis (GFC) of 2008 caused much concern for African growth and development (Fallon \& Lucas, 2002; Rama, 2003). The possible negative fallout from the 2008 credit crunch seemed particularly severe for Africa, given the potentially disastrous implications that reduced economic growth could have for human development efforts on the continent.

As the GFC unfolded, however, Africa appeared to be very resilient. There was even speculation that, given the strong growth performance of certain African countries, the business cycle of the continent had managed to decouple from those of the advanced economies. In fact, the decoupling hypothesis that became prominent during the GFC caused a plethora of business cycle analyses on emerging markets and reawakened people's interest in understanding business cycle co-movement between countries. An analysis of patterns of co-movement for Africa as a whole, however, has been lacking.

This paper is an attempt to fill this gap by analysing the co-movement of business cycles between the African economies and AEs covering the period 1980 and 2011. We choose this period as it covers the period of structural reforms adopted by many countries in the continent. In addition, the mid-1990s witnessed an unprecedented rise in the economic growth rate as a consequence of globalisation, which was again amplified in the early 2000s. Finally, this period encompasses the years before, during, and immediately after the GFC. We use the Dynamic Factor Model (DFM) to measure the degree of co-movement between the business cycles of different groups of African countries among themselves and compared with AEs.

DFMs are becoming increasingly popular in empirical studies because of their ability to extract information from a large panel of time series without running out of a degree of freedom, like it happens in most Vector Autoregressive (VAR) analyses. For example, Ross (1976) uses a DFM to estimate an arbitrage pricing theory. It is evident in the literature that these models outperform traditional timeseries models in out-of-sample forecasting (Clavel \& Minodier, 2009; Altissimo, Cristadoro, Forni, Lippi \& Veronese, 2010). This paper follows closely Marcellino, Stock and Watson (2000); Mansour (2003); Kose, Otrok and Whiteman (2003); Helbling and Bayoumi (2003); Kabundi and Mouchilli (2009); Crucini, Kose and Otrok (2011); Kose, Otrok and Prasad (2012); and Çakir and Kabundi (2013) - all of whom use the DFM to measure the co-movement of macroeconomic and financial variables from a large panel of time series.

Alternatively, we could use a pairwise correlation between different growth models and determine the degree of co-movement based on the correlation coefficient. Similarly, we could use the co-integration analysis which is another useful way of assessing long-run correlation in time series. However, these methods are unable to accommodate a large cross-section of time series without running the risk of losing 
some degree of freedom and hence arriving at wrong conclusions. Besides the DFM, the Global VAR, the Panel VAR, and the large Bayesian VAR can accommodate a large cross-section of time series without the so-called 'curse of dimensionality'. However, the last category of empirical techniques is mostly used to assess the reaction of shocks from one variable in the panel to one or more variables in the panel. But these techniques are not appropriate to assess the degree of co-movement in a large cross-section of time series like the DFM.

The remainder of the paper is organised as follows: Section 2 provides a brief theoretical background and literature review about the co-movement of business cycles; Section 3 discusses an overview of the economic performance of African economies; Section 4 provides a discussion of the DFM; Data are described in Section 5; Section 6 discusses the empirical results, and Section 7 concludes.

\section{Theoretical background and literature review on co- movement between African and advanced economies}

The theoretical basis for co-movement and potential decoupling stems from an understanding of the influence of the business cycle between countries and is embedded in the international business cycle theory and the role of transmission mechanisms.

A seminal investigation into the empirical facts and theories behind the international business cycle was carried out by Backus, Kehoe and Kydland (1992). Their work builds on the theory developed by Kydland and Prescott (1982), who investigated why co-movement occurs across variables in a domestic economy.

In the Backus et al. (1992) model, the global economy consists of two countries with complete markets for state-contingent claims, each producing one homogeneous product. These countries are subject to technology shocks in different periods. Economic agents participate in international capital markets and trade is frictionless, although labour is immobile. Backus et al. (1992) introduce openness to the model in which agents use international markets as a mechanism of sharing risk and smoothing consumption. This leads to negative output correlations across countries, since a positive technology shock in one economy will encourage capital flows from others. In this manner, events occurring in one economy may influence the real economy of another.

Contrary to these authors, Baxter and Crucini (1995) find evidence of positive correlation between output when one of the two economies is not fully integrated into the global financial markets. Their model is based on a restricted asset market where non-contingent bond trading is possible. The positive correlation is due to the wealth effect that comes into play when output in one country increases as a 
result of a productivity shock. In a complete market, residents of a foreign economy would be able to lower their labour input when a positive production shock occurred in their neighbouring economy. This would happen because the foreign residents anticipate the positive wealth effect that will accompany this increased productivity when it reaches their own economy. If the wealth effect is not as large as expected, residents have access to complete asset markets with which to smooth consumption. In the absence of this insurance that is presented by complete markets, however, the tendency for foreign labour input to decline is less. However, Baxter and Crucini (1995) conclude that the degree of co-movement is still not large enough to theoretically explain the trends observed in the data.

Backus, Kehoe and Kydland (1994) investigate the influence of trade on business cycles in their two-country model in which countries produce specialised goods using both capital and labour. They further assume imperfect substitutability of goods produced between the countries where labour is immobile. In their model goods produced in each country have both domestic and foreign contents, with the exact share of domestic to foreign inputs being determined by an Armington aggregator, which is a measure of elasticity of domestic to foreign goods. The net exports of each country in this model will be countercyclical. This is because net exports can be seen as the difference between output and the sum of consumption and investment in each economy, so that whatever is not consumed or invested locally is exported. Since consumers wish to smooth consumption between economies, investment will be procyclical. When output increases, it is possible to invest more, suggesting that the difference between output and the sum of consumption and investment narrows. Net exports, therefore, decline. Conversely, when output decreases locally, it is not possible to invest more. Net export increases as a consequence of the rise in the difference between output and the sum of consumption and investment.

Canova and Dellas (1993) propose a two-country model where each country specialises in the production of a different good which can be consumed as a good or used as an input in the production of another good. In this framework, an increase in output of the exporting country results in an increase in its exports. It implies that the importing country now has more goods which can be used as inputs in the production process, hence increasing the output of the importing country. In this manner, it is plausible for trade to be the underlying force behind the comovement of the two countries. This is in contrast to the negative correlation proposed by Backus, Kehoe and Kydland (1994). It suggests that economies that trade extensively tend to portray more synchronisation of business cycles (Canova \& Dellas, 1993; Frankel \& Rose, 1998; Clark \& Van Wincoop, 2001).

This idea of the imported business cycle, as referred to by Canova and Dellas (1993), might be particularly relevant to modern emerging markets, as the world has seen increased vertical specialisation of trade (Hummels, Ishii \& Yi, 2001). 
Kose and Yi (2001) extend the Backus et al. (1994) model by incorporating transport costs and allowing for the back and forth trade of goods between the two economies according to the standard international business cycle theory. The model allows for one country to sell a particular good to another country, which uses it as an input in the production process and then sells the final good back to the original country. In this case low transportation costs play a significant role for greater trade integration and, therefore, greater co-movement. However, Kose and Yi (2001) also suggest that low transportation costs could also more easily enable resource shifting between countries, which in turn could decrease business cycle co-movement. The model suggests that the resource-shifting effects of transportation costs dominates the trade integration effects.

In summary, the expectations that can be formed about decoupling between emerging market economies and AEs are not clear. International business cycle theory argues that increased financial integration would cause lower synchronisation, as it becomes possible for countries to share risk on international capital markets. This leads to the expectation that emerging market economies could have decoupled by diversifying risks on capital markets. On the other hand, the model developed by Baxter and Crucini (1995) showed that a low degree of financial integration would likely lead to greater co-movement with advanced economies. It is also possible that, at certain times in a business cycle, risk sharing is not possible because markets themselves are the source of risk.

Regarding trade, the theoretical expectations are also unclear. It is possible that the higher levels of trade integration seen in the global economy could have served to lower levels of business cycle co-movement - again due to the risk sharing that is possible within an open economy framework. It is possible, therefore, that emerging market economies could have shown lower business cycle correlations owing to consumption smoothing made possible by trade and vertical specialisation. On the other hand, there is the possibility that countries that trade intensively would likely import business cycles, implying that emerging market economies would have experienced higher levels of business cycle synchronisation during the GFC.

It is worth mentioning that trade and finance could serve as channels through which the shock from one country is transmitted to another. Importantly, not only the transmission of the shock but also the very nature of the shock could cause the comovement of cycles between countries. This happens when the shocks are common to both countries (Stockman, 1988). For example, an oil price shock can affect two countries simultaneously, resulting in a synchronisation of economic variables even when there is no evidence of a spillover. According to Dellas (1986), shared supply shocks and the adoption of similar policies in order to cope with such shocks are the important factors behind the co-movement of the business cycles of Germany, Japan, the United Kingdom (UK), and the United States (US). Similarly, Jansen 
and Stockman (2004) argue that economic shocks exert co-movement in outputs whereas idiosyncratic shocks result in the opposite. But idiosyncratic shocks can still spill over from one country to another through trade and financial linkages.

With reference to the existing literature on the topic, the analysis of African comovement tends to take a regional focus, or to focus specifically on the comovement between one specific African country and an advanced partner. To offer a broad background on the issue, the literature covered in the ensuing paragraph discusses previous studies conducted on African co-movement with AEs and/or BRIC (Brazil, Russia, India and China) economies in the period 2000 to 2014.

Table 1 provides a summary of the relevant and recent studies on co-movement of cycles across Africa. Kabundi and Loots (2007), for example, analyse the comovement between business cycles in the Southern African Development Community (SADC). Ndulu and O'Connell (2007) use pooled conditional regressions to analyse the sensitivity of African growth rates to exogenous shocks between 1960 and 1997; they conclude that trading partner growth is a significant determinant of African growth, with African economies expanding by $0.4 \%$ in reaction to a $1 \%$ increase in trading partner growth. Drummond and Ramírez (2009) study 40 African economies between 1980 and 2008 using dynamic panel growth regression and find evidence of a slowdown in the economic growth of the sub-Saharan Africa (SSA) region caused by the weaknesses in global growth. A percentage point decrease in the global economy leads to a 0.4 percentage point drop in SSA growth. The main transmission mechanism is the income effects from changes in non-fuel commodity prices and oil prices. Similarly, Bangwayo-Skeete (2012) employs a generalised method of moments approach, covering the period 1961 to 2005. His results support the view that African countries are still highly dependent on AEs. However, Diallo and Tapsoba (2014) as well as Ncube, Brixiova, and Meng (2014) do not find evidence of co-movement between the SSA region and the rest of the world. Interestingly, Ncube, Brixiova and Meng (2014) indicate that regional factors from the Eastern African Community (EAC) and the Southern African Customs Union (SACU) are more important for these regions than the continental factor.

As seen from the literature review, the literature on co-movement between Africa and the rest of the world, especially advanced economies, is sparse. In general, though, the picture that emerges from the available literature is one of a continent that is still very susceptible to changes in trading partners' economic conditions. Europe in particular has traditionally been an important trading partner for much of SSA and the literature shows that this has remained largely true in recent years, with changes in European growth having important spill-over effects on African growth. This is not to say that trading partners have remained the same throughout, though. While AEs in the Eurozone in particular still have a strong influence on growth in African economies, the literature suggests that the US and other G7 
trading partners have become less dominant players as African trade has shifted increasingly towards other developing and emerging partners.

Table 1: Literature on co-movement between Africa and advanced economies

\begin{tabular}{l|l|l|l}
\hline Authors & $\begin{array}{l}\text { Period } \\
\text { covered }\end{array}$ & Method used & Main conclusion \\
\hline $\begin{array}{l}\text { Bangwayo- } \\
\text { Skeete (2012) }\end{array}$ & $1961-2005$ & GMM & $\begin{array}{l}\text { The global business cycle significantly } \\
\text { influences Africa's economic growth. }\end{array}$ \\
\hline $\begin{array}{l}\text { Diallo and } \\
\text { Tapsoba } \\
(2014)\end{array}$ & $1970-2010$ & $\begin{array}{l}\text { Instrumental } \\
\text { variables }\end{array}$ & $\begin{array}{l}\text { SSA displays less sensitivity to G7 shocks, } \\
\text { but is co-moving more with BRIC } \\
\text { countries. }\end{array}$ \\
\hline $\begin{array}{l}\text { Drummond } \\
\text { and Ramírez } \\
(2009)\end{array}$ & $1980-2008$ & $\begin{array}{l}\text { Dynamic panel } \\
\text { growth } \\
\text { regressions }\end{array}$ & $\begin{array}{l}\text { A 1.0 per cent decline in world growth } \\
\text { slows SSA growth by 0.4 per cent on } \\
\text { average. }\end{array}$ \\
\hline $\begin{array}{l}\text { Gurara and } \\
\text { Ncube (2013) }\end{array}$ & $1980-2011$ & GVAR & $\begin{array}{l}\text { African growth is still very responsive to } \\
\text { European slowdowns, with 1.0 per cent } \\
\text { lower European growth leading to 0.6 per } \\
\text { cent lower growth for Africa. }\end{array}$ \\
\hline $\begin{array}{l}\text { Ncube, } \\
\text { Brixiova and } \\
\text { Meng (2014) }\end{array}$ & $1980-2011$ & SVAR & $\begin{array}{l}\text { Idiosyncratic factors, not common } \\
\text { components, explain output fluctuations in } \\
\text { African economies. }\end{array}$ \\
\hline $\begin{array}{l}\text { Ndulu and } \\
\text { O'Connell } \\
(2007)\end{array}$ & $1960-2007$ & $\begin{array}{l}\text { Pooled } \\
\text { conditional } \\
\text { regression }\end{array}$ & $\begin{array}{l}\text { Trading partner growth is a significant } \\
\text { determinant of African growth. }\end{array}$ \\
\hline
\end{tabular}

Although a few studies do include samples that cover the GFC, these have been for more narrow sets of countries. Ncube et al. (2014), for instance, focus only on the Southern African Customs Union (SACU) and East African Community (EAC) countries. None of these studies has used a DFM or looked at SSA countries on the basis of income group rather than region. The focus of VAR models used in many of these studies is on estimating the size of spill-over effects and not determining exactly what the factors are that drive co-movement. The use of a DFM and income groups for the period spanning the GFC is the contribution made by this paper's empirical analysis.

\section{African growth performance before, during and immediately after the global financial crises}

To provide background to the empirical analysis, this section focuses specifically on African's growth performance in the years 1980 to 2011 . We emphasise three periods, namely the periods before, during, and immediately after the GFC. The analysis sheds light on whether the continent decoupled from AEs during and after the GFC. 
Figure 1 clearly shows an increasing trend in the economic growth of the continent between 1980 and 2012. Sahn, Dorosh and Younger (1999) identify factors such as policy reform focusing on macroeconomic stability and liberalisation as well as political stability as the key drivers of the strong growth in this recent period.

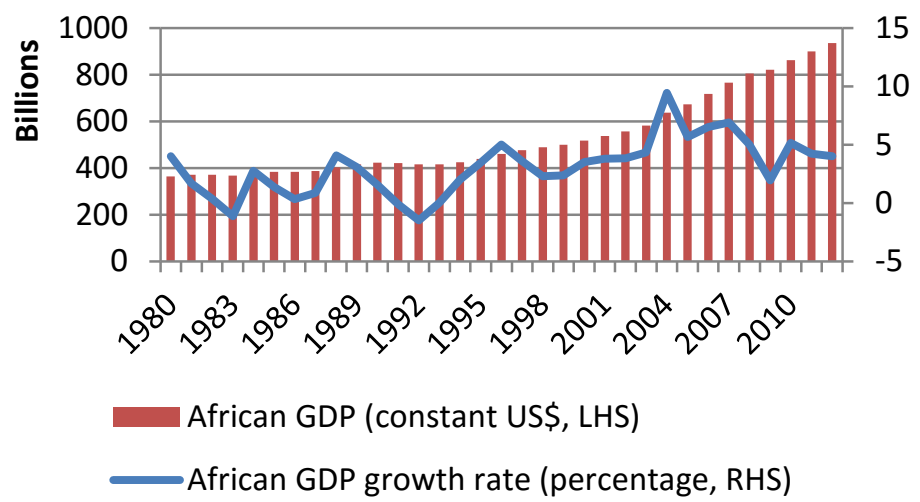

Figure 1: African GDP trends, 1980-2012

Source: World Development Indicators

What is also clear from Figure 1 is that African gross domestic product (GDP) growth has been rather erratic, with many upturns and downturns. Africa's poor growth performance during the 1990s can also be clearly seen. By 1992, growth on the African continent had dipped to well below its 1980 level, only recovering around 1996. Growth then plummeted once more, although not as drastically as during the early 1990s, and remained close to approximately 3 per cent until the early 2000s. Only then did it become evident that the reforms implemented during the 1990s had started to pay dividends, supported by the favourable global environment as discussed by Carmody (2011) as well as African policy reforms helping to put growth on a much stronger path. African growth shot up in 2003, with the continent's GDP standing at approximately US\$ 800 billion right before the GFC in 2007. African growth was clearly influenced by the GFC as the growth rate declined from 7 per cent in 2007 to 2 per cent in 2009. After 2009, growth did recover although not to pre-crisis levels.

Figure 2 compares the growth performance of Africa during the GFC relative to its own past, to developed economies, and to the world. Compared with global growth and growth in advanced economies especially, African growth during the GFC was lower than before, but still fairly strong. The developed economies as a group experienced contractions in their economies in those years, with an average GDP 
growth rate of only 0.42 per cent between 2008 and 2011. During the same period, Africa as a whole still managed to grow by an average of just over 4 per cent.

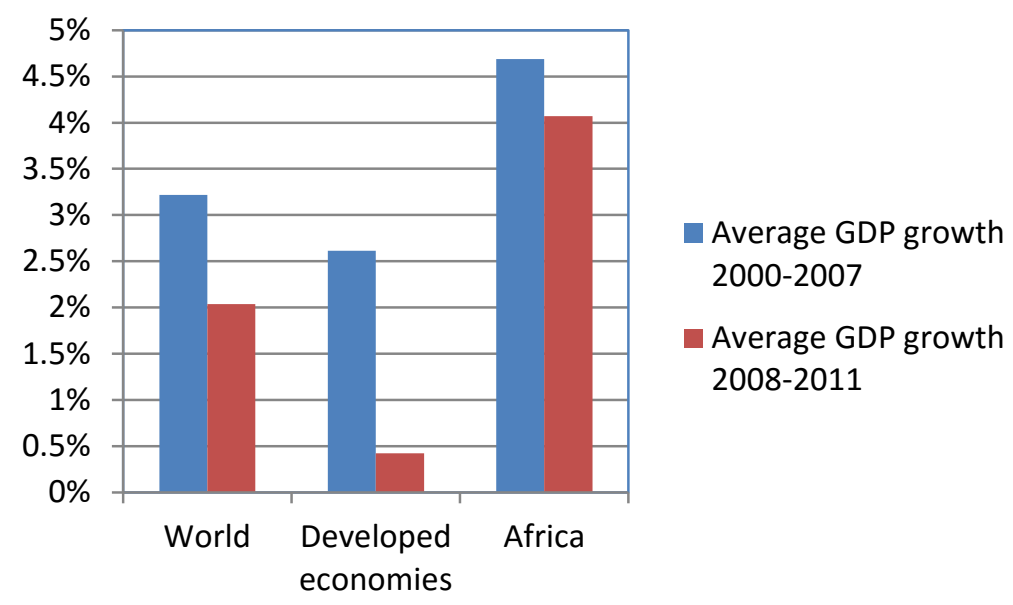

Figure 2: African growth versus advanced economy growth: Before and during the GFC

Source: World Development Indicators

But, since African countries are heterogeneous, we expect them to react somewhat differently to shocks. There are various ways of looking at the divergence in responses to common shocks. One way is to group countries according to their geographical location. Kabundi and Loots (2007) show that similarity in Africa tends to emerge when geography is used as a criterion of classification. Five main groups emerge from this classification, namely North Africa, West Africa, East Africa, Central Africa and Southern Africa.

Figure 3 shows the growth performance of these five regional groups before and after the GFC.

It can be seen from Figure 3 that the Central African region showed the strongest contraction of the five regions - from an average annual growth rate of 7 per cent up until 2007 to an average growth of 4.4 per cent from 2008 to 2011. Other regions seemed to fare somewhat better. Surprisingly, West Africa's and East Africa's growth increased notably during the crisis years, with average growth rates rising from 4.5 to 4.7 per cent and from 3.9 to 4.8 per cent, respectively. The likely reason for this is mainly because of the dominance of idiosyncratic factors as the region is still not very integrated into the global economy. Seck (2010) points out that West Africa's share of global trade has been steadily declining and that the 
region is not a popular destination for FDI flows. It is also likely that the good growth performance seen in the West African region can largely be attributed to Nigeria, which fared well throughout the GFC. This was due to proactive government policy and an expanding non-oil sector that shielded the Nigerian economy from the worst of the volatility in oil markets at the time of the crisis. North Africa and Southern Africa both experienced declines in growth during the crisis years, with North Africa contracting from a pre-crisis average annual growth rate of just over 5 per cent to just below 4 per cent. Southern Africa's economic growth rate declined from just over 4 per cent to just below 3 per cent.

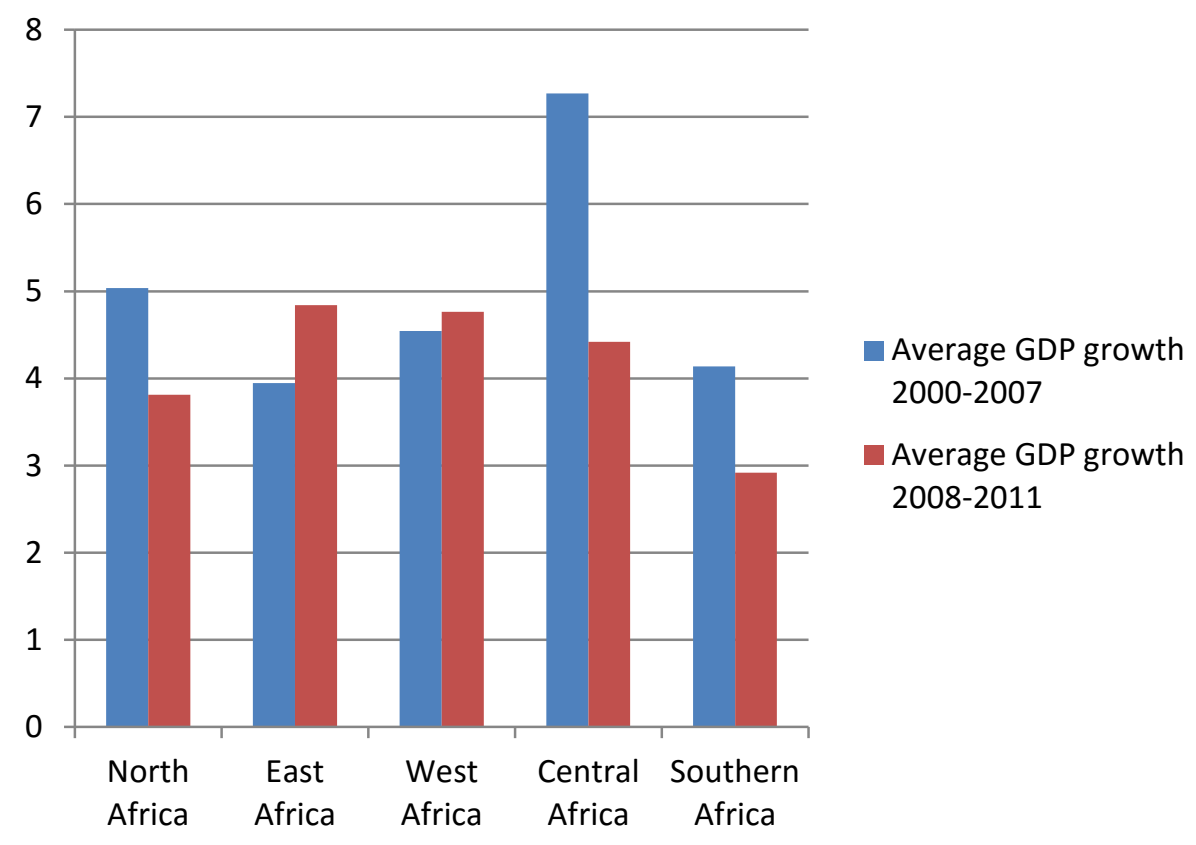

Figure 3: African GDP growth by region, 2000-2011

Source: African Development Indicators

It should be noted, though, that this regional averaging of growth does not accurately illustrate the expected impact of the crisis on individual countries. The presence of some of Africa's largest economies, such as Nigeria and South Africa, means that the regional averages are skewed towards these large economies. 
The second category of classification is in terms of the size of the economy. ${ }^{1}$ Similarly to the geographical classification, countries with a similar size of the economy turn out to have a similar reaction to common shocks. According to this classification, we identify four groups, namely low-income countries, middleincome countries, oil-exporting countries and fragile states. The performance of these four groups is represented in Figure 4.

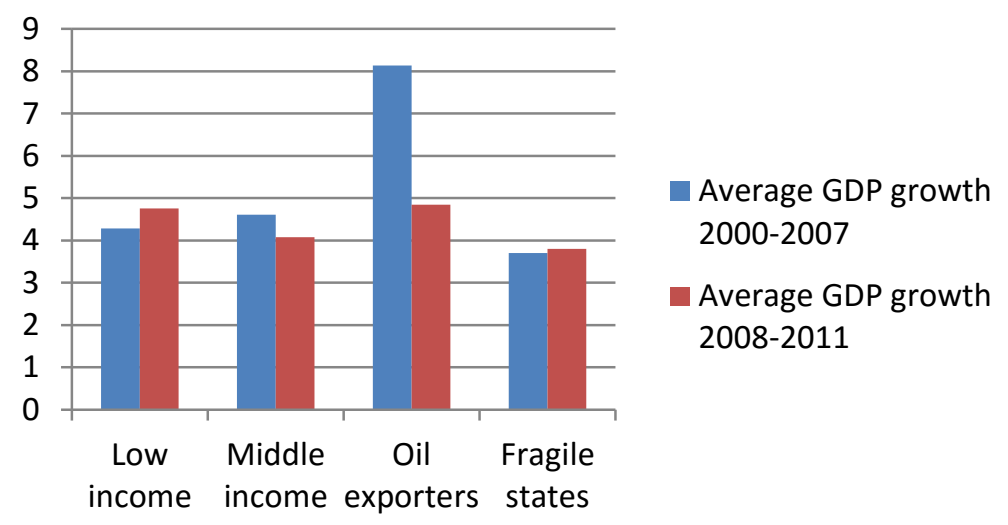

Figure 4: African GDP growth by group, 2000-2011

Source: African Development Indicators

In the years leading up to the GFC, low- and middle-income economies in Africa displayed steady economic growth, with average annual rates of 4.6 and 4.2 per cent, respectively. During the crisis years of 2008 to 2011, however, middle-income economies were negatively influenced, bringing down their annual growth to an average of 2.8 per cent. Strangely, the low-income economies portrayed a different pattern, registering instead a slight increase in their average annual growth to 4.6 per cent.

Oil-exporting countries clearly were the worst affected group and suffered large contractions during the crisis years. Pre-crisis growth had averaged 8.1 per cent per year for this group. During the crisis years, growth contracted and oil exporters grew by an average of 4.9 per cent. This highlights the important links that commodities have to global financial markets for many oil-exporting countries (Cramer, Johnston \& Oya, 2009). The oil price plummeted from above US\$120 a barrel before the GFC to US $\$ 40$ after the GFC, which in turn had considerable negative effects on the oil-dependent economies. Similarly, Kasekende, Brixova

1 See the International Monetary Fund (2014) for more explanation on the classification. 
and Ndikumana (2010) also find that resource-rich economies in Africa were much more heavily influenced than their counterparts were.

Fragile states managed to increase their growth during the GFC. This is attributable to the fact that growth in these economies is predominantly caused by idiosyncratic, as opposed to global, factors. These economies are classified as fragile states because of a host of structural characteristics such as low levels of development, trade restrictions, conflict and/or their post-conflict status. The divergence of growth rates across the continent throughout the GFC period reflects in the policy responses to the shocks. Many African economies had managed to build up solid surpluses and reserves in the years leading up to the GFC. For these economies, it was possible to institute the necessary counter-cyclical policies. Other African economies applied expansionary monetary policies in reaction to the global economic downturn. These were mostly Africa's emerging economies, most of which used a blend of fiscal and monetary policies and measures in an attempt to stimulate their local economies. Other countries, especially the fragile states, were not in the same favourable position (Kasekende et al., 2010).

Against this backdrop, the nature of the co-movement between African countries and AEs, before, during, and immediately after the GFC, is still not evident. Importantly, given the heterogeneous nature of African countries, it is still not evident which African economies co-move more with AEs and which co-move less. Furthermore, it is possible to have strong co-movement before the GFC and then countries decoupling afterwards, and vice versa. We use the DFM to answer these questions.

\section{Dynamic factor model}

The DFM divides each time series into two unobserved components, namely the common factor (which is common to all the series included in the panel) and the idiosyncratic factor (which is specific to each series). In this particular context, each growth rate contains a common factor that is common across the continent and, in some cases, also common with AEs, as well as factors that represent the dynamics of growth in each country.

Assume a vector of time series, $Y_{t}=\left(y_{1 t}, y_{2 t}, \cdots y_{N t}\right)^{\prime}$, as the sum of the common component, $X_{t}=\left(x_{1 t}, x_{2 t} \ldots x_{N t}\right)^{\prime}, \quad$ and the idiosyncratic component, $e_{t}=$ $\left(\varepsilon_{1 t}, \varepsilon_{2 t \ldots} \varepsilon_{N t}\right)^{\prime}$, represented as

$$
Y_{t}=X_{t}+e_{t}
$$


Equation (1) can also be written as

$$
Y_{t}=\Lambda F_{t}+e_{t}
$$

where $F_{t}$ is a vector of $r$, the common factor, and $\Lambda$ is the $N \times r$ matrix of factor loadings such that $r \ll N$. From (1) and (2), we can infer the common component $X_{t}=\Lambda F_{t}$, and $e_{t}$ as a $N \times 1$ vector idiosyncratic component, which is that part of each time series that is variable-specific to each series. Note that the common factors and idiosyncratic factors are orthogonal. In addition, the common factors are orthogonal among themselves.

We can extract the common factors using the principal component analysis as $T, N \rightarrow \infty$ by exploiting the variance matrix which maximises the co-variance of the series in the panel. The first principal component of the common components can be identified using the eigenvector corresponding to the highest eigenvalue. We proceed in a similar fashion for the second principal component, and so on. Mathematically, we have

$$
X_{t}=V V^{\prime} Y_{t}
$$

where $V$ is the $N \times r$ matrix of eigenvectors that correspond to the largest $r$ eigenvalues. From (3), it follows that the common factors are extracted as follows

$$
F_{t}=V^{\prime} Y_{t}
$$

Finally, we estimate the dynamic factors from a VAR(1) representation as

$$
F_{t}=\Gamma F_{t-1}+\Psi_{t}
$$

\section{$5 \quad$ Data and data transformation}

Given the diverse performances of various groups of African economies, individual African economies are grouped in categories according to the size of the economy, namely low-income countries, middle-income countries, oil-exporting economies and fragile states. We construct variables of each group using GDP purchasing power parity (PPP) weights. The classification of countries according to these groups is that of the $\mathrm{IMF}^{2}$, and the following countries are included:

\footnotetext{
${ }^{2}$ The IMF classifies countries according to their Gross National Income per capita. Additionally, a Resource Allocation Index provides an indication of the structure of the economy. Full information on the classification of Sub-Saharan African economies can be obtained from https://www.imf.org/external/pubs/ft/reo/2015/afr/eng/pdf/statistical1015.pdf.
} 
- Low-income countries: Benin, Burkina Faso, Ethiopia, Gambia, Kenya, Madagascar, Malawi, Mali, Mozambique, Niger, Rwanda, Sierra Leone, Tanzania, Uganda.

- Middle-income countries: Botswana, Cape Verde, Ghana, Lesotho, Mauritius, Namibia, Senegal, Seychelles, South Africa, Swaziland, Zambia.

- Oil exporters: Nigeria, Angola, Cameroon, Chad, Congo (Rep), Equatorial Guinea, Gabon.

- Fragile states: Burundi, Central African Republic, Comoros, Democratic Republic of the Congo (DRC), Côte d'Ivoire, Eritrea, Guinea, Guinea Bissau, Liberia, São Tome, Togo, Zimbabwe.

Annual data for the period between 1980 and 2011 is obtained from the African Development Indicators database of the World Bank. This dataset includes figures on the GDP, imports, exports, consumer price index (CPI), foreign direct investment (FDI) inflows, official development assistance (ODA) receipts and the business cycle. Business cycles are extracted from GDP using the HP filter. Indices for oil prices, as well as food and mineral prices, are also included as global variables. Annual data for G7 variables, such as imports and exports, GDP, CPI, producer price index (PPI) and unemployment, is obtained from the Federal Reserve Economic Data (FRED) database. This results in a sample of 37 observations $(\mathrm{N})$ over 31 years $(\mathrm{T})$.

All data is logged (except the FDI and unemployment data) and checked for stationarity using the Augmented Dickey-Fuller (ADF) test. Where necessary, and as indicated by the ADF, data is differenced in order to ensure stationarity before proceeding with the factor analysis. Two factors are specified according to the Alessi, Barigozzi and Capasso (2010) (ABC) criteria.

\section{$6 \quad$ Model results}

The first task in the DFM is to determine the number of factors to include in the estimation. We select two factors based on the criteria by Alessi, Barigozzi, and Capasso (2010) (ABC). It is more likely that the analysis of co-movement between African countries is affected by the presence of a common global factor. It makes sense that countries may not have trade and/or financial linkages but still depict a co-movement which comes mainly from a strong tie to a common source of shock. For example, the European Union (EU), being one of the most important trading partners of African countries, may induce strong co-movement between countries even in the absence of a bilateral trade and/or financial linkage. To deal with this issue, we first extract common factors from a panel comprising variables from African countries and the G7. Secondly, we then identify the nature of these common factors. It is clear that the extracted factors emanate from the G7 grouping as they depict a strong co-movement with G7 variables. Thirdly, we remove the 
effects of the G7 factors on African variables by taking the residual of the regression of each variable on the factors. Finally, we extract common factors from the residuals.

Table 2 presents the variance shares of the common components from the entire sample, i.e. Africa, the G7 countries, and commodity prices. It is clear from the table that G7 variables score highly, especially the trade variables. It means that trade linkages constitute the channel through which these countries are linked. More specifically, the table depicts that the variance shares of the common components are 75 per cent and 68 per cent for G7 imports and exports respectively. Among the African groups, the low-income countries score the highest variance shares of 62 per cent and 69 per cent for imports and exports respectively. This is followed by the middle-income group, the fragile states, and lastly the oil-exporting countries.

The results imply that low-income countries depend highly on trade with AEs and that the oil-exporting countries are mainly driven by idiosyncratic factors. Recall that the latter group witnessed unprecedented growth from a record rise in oil prices before the GFC. In addition, the results emphasise the evidence of the heterogeneity of these countries, observed when assessing the growth performance of each block; treating them as homogenous is thus misleading.

Interestingly, the variance shares of GDP give a different picture. In this case, the middle-income region has the highest variance share, followed by the low-income group and the oil-exporting block. The fragile states are last with a variance share of 22 per cent.

Looking at the business cycle, the middle-income group still comes in the first position, followed by the fragile-states group, then the low-income countries, and finally the oil-exporting economies.

As mentioned above, these results are probably affected by the presence of the G7 factors. This is consistent with the view of the IMF (2008), which points out that the difference in the performance of the oil-exporting countries is based mainly on idiosyncratic factors such as instability in both Chad and Nigeria. 
Table 2: Variance share of the common components from Africa and the G7, 1981-2011

\begin{tabular}{|c|c|c|c|c|c|}
\hline & G7 & Low income & Middle income & $\begin{array}{c}\text { Fragile } \\
\text { states }\end{array}$ & $\begin{array}{c}\text { Oil } \\
\text { exporters }\end{array}$ \\
\hline GDP & 0.27 & 0.35 & 0.45 & 0.22 & 0.35 \\
\hline Imports & 0.75 & 0.62 & 0.41 & 0.39 & 0.11 \\
\hline Exports & 0.68 & 0.69 & 0.23 & 0.15 & 0.31 \\
\hline ODA & & 0.00 & 0.39 & 0.07 & 0.08 \\
\hline FDI & & 0.06 & 0.04 & 0.13 & 0.14 \\
\hline CPI & 0.25 & 0.05 & 0.05 & - & 0.12 \\
\hline Business cycle & 0.26 & 0.12 & 0.38 & 0.34 & 0.05 \\
\hline PPI & 0.59 & & & & \\
\hline Unemployment & 0.23 & & & & \\
\hline
\end{tabular}

As mentioned earlier, the results in Table 2 can be misleading because of the possibility of the co-movement stemming from trade and/or financial ties with AEs. To isolate the effects of G7, we extract common factors from the residuals obtained from the regression of African variables on the common factors. We can easily assign to these factors the label of 'African factors'. The results in Table 3 are the variance shares of the common components from these African factors.

Notice the marked difference from the results presented in Table 2. Clearly, variance shares exhibit a pronounced co-movement in all the groups, except in the fragile-states block. This suggests that the co-movement observed in Table 2 does not imply that a strong linkage exists between African countries; it rather implies the opposite. This becomes clearer when we focus on the variance shares of trade and/or financial variables. They are all very low. Nevertheless, the fragile-states group displays high variance shares for GDP and imports. We interpret the rise in variance shares as evidence that the fragile states in Africa are less integrated with the global economy but show similarity with other African countries. Recall that these countries are characterised by political instability, war, a lack of sound macroeconomic policies, and little trade with the rest of the world. We therefore expect them to show similarity in their performance.

By comparison, the results in Table 3 indicate the dominance of idiosyncratic factors. We can interpret them as evidence of an absence of co-movement with the African factors instead of a relatively strong linkage with AEs. Besides the middleincome group, the business cycles of African countries are not explained by the African factors. In general, African countries are not integrated and have few trade and/or financial linkages. 
Table 3: Variance share of the common component from Africa excluding the G7 factor

\begin{tabular}{l|c|c|c|c}
\hline & Low income & Middle income & Fragile states & Oil exporters \\
\hline GDP & 0.08 & 0.40 & 0.65 & 0.02 \\
\hline Imports & 0.16 & 0.02 & 0.69 & 0.00 \\
\hline Exports & 0.25 & 0.02 & 0.11 & 0.00 \\
\hline ODA & 0.26 & 0.13 & 0.00 & 0.01 \\
\hline FDI & 0.03 & 0.14 & 0.01 & 0.01 \\
\hline CPI & 0.05 & 0.00 & - & 0.32 \\
\hline Business cycle & 0.11 & 0.40 & 0.03 & 0.04 \\
\hline PPI & \multicolumn{4}{|l}{} \\
\hline Unemployment & \multicolumn{4}{|l}{}
\end{tabular}

\section{Conclusion}

This paper assesses the co-movement between African countries using annual time series from 1980 to 2011. Given the heterogeneous nature of African countries, we divide the continent according to geographical location and the size of the economy. The graphical analysis of the economic growth rate shows differences in performance relative to their past and between groups. Four of the five groups perform poorly after the GFC compared to before the GFC. However, the classification according to the size of the economy reveals a slowdown in the middle-income and oil-exporting countries whereas the low-income group and the fragile states perform much better after the GFC.

In order to shed light on patterns of African co-movement in the years leading up to, during and immediately after the crisis, this article analysed co-movement between African and the G7 economies, using a Dynamic Factor Model. The results suggest that two factors are enough to explain a large portion of movement in the panel. The common factors emanate from the G7 countries as they depict strong co-movement with the trade variables of these countries.

The empirical analysis concludes that middle-income African countries are the only group that shows consistent business cycle variance shares, both before and after controlling for the influence of the G7. This implies that while middle-income African countries have coupled to the G7 business cycle since the 1980s, they have also coupled among themselves. This suggests higher levels of intraregional finance and trade among these economies. Before controlling for the G7, low-income economies showed high variance shares for imports and exports. This shows that trade is an important transmission mechanism for low-income African economies.

When controlling for the G7, however, variance shares decline. This confirms the importance of trade with advanced economies for low-income African countries. 
Fragile states display an interesting pattern. Business cycle co-movement for this group is comparable to that of middle-income countries when including the G7, indicating that fragile states are more coupled to the G7 than oil exporters and lowincome economies are. However, when controlling for the G7, the business cycle variance share decreases dramatically. This suggests that the initial coupling seen was entirely due to the common effect of the G7 as a shared trading partner for these economies. While removing the $\mathrm{G} 7$ decreases business cycle variance shares, it increases variance shares in GDP and imports, suggesting that fragile states rely much more on trade with other African groups than with the G7. Oil-exporting economies show low variance shares throughout the analysis - both when including and excluding the influence of the G7. There has been quite strong decoupling for oil exporters, therefore. This result suggests that idiosyncratic disturbances in these economies are most important for business cycles. Oil exporters should direct their policy on ensuring stable macroeconomic and political environments.

Finally, the fact that $\mathrm{G} 7$ trade emerges as an explanatory factor in the empirical analysis underlines a recurrent theme throughout this paper, i.e. trade fosters comovement. For the African groups studied here, trade with the G7 still dominates, as seen in the impact that the removal of the G7 factor had on variance shares. The management of trade policies is therefore important for African policymakers. Diversified trade could shield economies from future advanced economic crises.

\section{References}

Alessi, L., Barigozzi, M. \& Capasso, M. 2010. 'Improved penalization for determining the number of factors in approximate factor models', Statistics and Probability Letters, 80(23-24): 806-1813.

Altissimo, F., Cristadoro, R., Forni, M., Lippi, M. \& Veronese, G. 2010. 'New Eurocoin: Tracking economic growth in real time', The review of economics and statistics, 92(4): 10241034.

Backus, D.K., Kehoe, P.J. \& Kydland, F. 1994. 'Dynamics of the trade balance and the terms of trade: The J-Curve?', The American Economic Review, 84(1): 84-103.

Backus, D.K., Kehoe, P.J. \& Kydland, F.E. 1992. 'International real business cycles', Journal of Political Economy, 745-775.

Bangwayo-Skeete, P.F. 2012. 'Do common global economic factors matter for Africa's economic growth?', Journal of International Development, 24(3): 304-315.

Baxter, M. \& Crucini, M.J. 1995. 'Business cycles and the asset structure of foreign trade', International Economic Review, 36(4): 821-854.

Çakır, M.Y. \& Kabundi, A. 2013. 'Business cycle co-movements between South Africa and the BRIC countries', Applied Economics, 45(33): 4698-4718. 
Canova, F. \& Dellas, H. 1993. 'Trade interdependence and the international business cycle', Journal of International Economics, 34(1): 23-47.

Carmody, P. 2011. The new scramble for Africa. Cambridge, UK, and Malden, MA: Polity Press.

Clark, T.E. \& Van Wincoop, E. 2001. 'Borders and business cycles', Journal of International Economics, 55(1): 59-85.

Clavel, L. \& Minodier, C. 2009. A monthly indicator of the French business climate. Working Paper, Institut National de la Statistique et des Études Économiques (Insee).

Cramer, C., Johnston, D. \& Oya, C. 2009. 'Africa and the credit crunch: From crisis to opportunity’, African Affairs, 108(433): 643-654.

Crucini, M.J., Kose, M.A. \& Otrok, C. 2011. 'What are the driving forces of international business cycles?', Review of Economic Dynamics, 14(1):156-175.

Dellas, H. 1986. 'A real model of the world business cycle', Journal of International Money and Finance, 5(3): 381-394.

Diallo, O. \& Tapsoba, S. 2014. Rising BRICs and changes in Sub-Saharan Africa's business cycle patterns. IMF Working Paper 14/35.

Drummond, P.F.N. \& Ramírez, G.P. 2009. Spillovers from the rest of the world into sub-saharan African countries. International Monetary Fund.

Fallon, P.R. \& Lucas, R.E. 2002. 'The impact of financial crises on labor markets, household incomes, and poverty: A review of evidence', The World Bank Research Observer, 17(1): 21-45.

Frankel, J.A. \& Rose, A.K. 1998. 'The endogeneity of the optimum currency area criteria', The Economic Journal, 108(449): 1009-1025.

Gurara, D.Z. \& Ncube, M. 2013. Global economic spillovers to Africa: A GVAR approach. African Development Bank.

Helbling, M.T. \& Bayoumi, M.T. 2003. 'Are they all in the same boat? The 2000-2001 growth slowdown and the G-7 business cycle linkages', International Monetary Fund Paper 3/46

Hummels, D., Ishii, J. \& Yi, K. M. 2001. 'The nature and growth of vertical specialisation in world trade', Journal of International Economics, 54(1): 75-96.

Jansen, W.J. \& Stockman, A.C. 2004. Foreign direct investment and international business cycle co-movement. ECB Working Paper No. 401.

Kabundi, A. \& Loots, E. 2007. 'Co-movement between South Africa and the Southern African development community: An empirical analysis’, Economic Modelling, 24(5): 737-748.

Kabundi, A. \& Mouchili, I. 2009. 'Stock market integration: A South African perspective', African Finance Journal, 11(2): 51-66. 
Kasekende, L., Brixova, Z. \& Ndikumana, L. 2010. 'Africa: Africa's counter-cyclical policy responses to the crisis', Journal of Globalisation and Development, 1(1): 1-20.

Kose, M.A., Otrok, C. \& Prasad, E. 2012. 'Global business cycles: Convergence or decoupling?', International Economic Review, 53(2): 511-538.

Kose, M.A., Otrok, C. \& Whiteman, C.H. 2003. 'International business cycles: World, region, and country-specific factors', American Economic Review, 1216-1239.

Kose, M.A. \& Yi, K.M. 2001. 'International trade and business cycles: Is vertical specialisation the missing link?', American Economic Review, 371-375.

Kydland, F.E. \& Prescott, E.C. 1982. 'Time to build and aggregate fluctuations', Econometrica, $1345-1370$.

Mansour, J.M. 2003. 'Do national business cycles have an international origin?', Empirical economics, 28(2): 223-247.

Marcellino, M., Stock, J.H. \& Watson, M.W. 2000. A dynamic factor analysis of the EMU. Working paper. http://www.Igier.uni-bocconi.it/whos.php.

Ncube, M., Brixiova, Z. \& Meng, Q. 2014. Can intra-regional trade act as a global shock absorber in Africa? African Development Bank Working Paper No 198.

Ndulu, B. \& O'Connell, S. 2007. Development deferred: Explaining Africa's economic growth, 1960-2000. Cambridge University Press.

Rama, M. 2003. Globalisation and workers in developing countries. World Bank Policy Research Working Paper 2958.

Ross, S.A. 1976. 'The arbitrage theory of capital asset pricing', Journal of Economic Theory, 13(3): 341-360.

Sahn, D.E. \& Younger, S.D. 2004. 'Growth and poverty reduction in Sub-Saharan Africa: Macroeconomic adjustment and beyond', Journal of African Economies, 13: 66-95.

Sahn, D.E., Dorosh, P.A. \& Younger, S.D. 1999. Structural adjustment reconsidered: Economic policy and poverty in Africa. Cambridge University Press.

Seck, D. 2010. The impact of the global financial crisis on West African states. Center for Research on Political Economy no. 008.

Stockman, A.C., 1988. 'Sectoral and national aggregate disturbances to industrial output in seven European countries', Journal of Monetary Economics, 21(2): 387-409. 